\title{
Pengaruh Mikrogravitasi Pada Biji Cabai Rawit yang Telah Terpapar Radiasi UVC Terhadap Laju Pertumbuhan Tanaman Cabai Rawit (Capsicum Frutescent L.)
}

Ni Nyoman Rupiasih*, Made Sumadiyasa and Ni Kadek Gita Hari Yanti

\begin{abstract}
Ringkasan
Telah dilakukan penelitian tentang pengaruh mikrogravitasi pada biji cabai rawit (Capsicum frutescent L.) yang telah terpapar radiasi UVC selama 1 jam terhadap laju pertumbuhan dan persentase hidup tanaman cabai. Lingkungan mikrogravitasi disimulasikan menggunakan klinostat 2-D dengan kecepatan rotasi 2,7 rpm. Biji terpapar radiasi UVC tersebut diberikan perlakuan mikrogravitasi selama 12 jam, 24 jam, dan 48 jam, yang secara berurutan disebut sampel S5, S6, dan S7. Sebagai pembanding adalah biji tanpa perlakuan (kontrol), biji dengan radiasi UVC selama 1 jam, biji dengan perlakuan mikrogravitasi selama 12 jam, 24 jam, dan 48 jam, yang secara berurutan disebut sampel S0, S1, S2, S3, dan S4. Semua kelompok sampel tersebut ditanam pada lingkungan gravitasi normal, $1 \mathrm{~g}$. Penelitian ini dilakukan selama fase vegetatif (sampai umur tanaman 40 hari). Pengukuran tinggi tanaman dan jumlah tanaman hidup dilakukan setiap hari. Hasil penelitian menunjukkan bahwa perlakuan mikrogravitasi pada biji cabai yang terpapar radiasi UVC selama 1 jam memberikan pengaruh negatif atau positif terhadap laju pertumbuhan tanaman cabai rawit. Besar pengaruh bergantung pada lama perlakuan yang diberikan dan fase pertumbuhan tanaman. Pada persentase tanaman hidup, tidak terdapat perbedaan antara sampel kontrol dan sampel dengan perlakuan mikrogravitasi.
\end{abstract}

Kata Kunci : mikrogravitasi, biji cabai rawit, radiasi UVC, laju pertumbuhan, persentase tanaman hidup

\section{Abstract}

A research on the effect of microgravity on cayenne pepper seeds (Capsicum Frustescent L.) that has been exposed to UVC radiation for $1 \mathrm{~h}$ on the growth rate and the percentage of plants life has been done. The microgravity environment was simulated using a 2-D clinostat with a rotational speed of $2.7 \mathrm{rpm}$. The seeds exposed to UVC radiation were given microgravity treatments for $12 \mathrm{~h}, 24 \mathrm{~h}$, and $48 \mathrm{~h}$, sequentially called as samples S5, S6, and S7. As comparison, it has been prepared a group of control such as Seeds without treatment (control), Seeds with UVC radiation for $1 \mathrm{~h}$, seeds with microgravity treatment for $12 \mathrm{~h}, 24 \mathrm{~h}$, and $48 \mathrm{~h}$, sequentially called as S0, S1, S2, S3, and S4 samples. All of the sample groups were planted in a normal gravity environment, $1 \mathrm{~g}$. This study was conducted during the vegetative phase (up to 40 days of plant life). Measurement of plant height and number of life plants is done daily. The results showed that microgravity treatment on cayenne pepper seed exposed to UVC radiation for $1 \mathrm{~h}$ gave negative or positive effects on the growth rate of cayenne pepper plant. The effect depends on the length of the given treatment and plant growth phase. In the percentage of life plants, there was no difference between control and samples with microgravity treatment.

Keywords: microgravity; cayenne seed; UVC radiation; growth rate; life plant percentage

\footnotetext{
${ }^{*}$ Correspondence: rupiasih@gmail.com

Department of Physics, Faculty of Mathematics and Natural Sciences, Udayana University, Bali, Indonesia

Full list of author information is available at the end of the article

${ }^{\dagger}$ Equal contributor
}

\section{Pendahuluan}

Belakangan ini, banyak aktivitas manusia yang menghasilkan bahan kimia berbahaya, seperti chlorofluorocarbons (CFC), hydrochlorofluorocarbons 
(HCFC) dan metil bromida yang menyebabkan pencemaran udara dan pemanasan global sehingga berdampak pada rusak dan menipisnya lapisan ozon. Penipisan atau rusaknya lapisan ozon secara terus menerus dapat meningkatkan intensitas radiasi ultraviolet (UV) yang mencapai permukaan bumi. Semakin banyaknya radiasi UV mencapai permukaan bumi, dapat berpengaruh buruk terhadap lingkungan dan juga kesehatan.

Radiasi ultraviolet (UV) merupakan salah satu komponen dari gelombang elektromagnetik dengan panjang gelombang antara 40-400 nm. Berdasarkan panjang gelombangnya, radiasi UV terdiri dari UV-vacuum dengan panjang gelombang 40-190 nm, UV-jauh dengan panjang gelombang 190-220 nm, UVA dengan panjang gelombang 320-400 nm, UVB dengan panjang gelombang 290-320 $\mathrm{nm}$ dan UVC dengan panjang gelombang 220-290 nm. Dari ketiga jenis radiasi UV tersebut, radiasi UVC memiliki panjang gelombang paling pendek atau memiliki tingkat energi tertinggi, kemudian diikuti oleh radiasi UVB, radiasi UVA, dan UV-vacuum [1].

Radiasi UV yang mencapai permukaan bumi memiliki dampak negatif terhadap pertumbuhan dan perkembangan makhluk hidup. Salah satu dampak yang ditimbulkan yaitu perubahan yang terjadi pada struktur DNA yang dapat menyebabkan kelainan genetik, kanker, dan lain-lain.

Beberapa penelitian telah dilakukan tentang pengaruh radiasi terhadap makhluk hidup khususnya pada pertumbuhan tanaman. Adriano, S., dkk. 2014 telah melaporkan bahwa biji tanaman tomat yang diradiasi UVC selama 60-120 menit (dosis tinggi) mengakibatkan kerusakan pada tingkat fisiologi dan morfologi tanaman tomat, khususnya pada daun dan tunas dapat menyebabkan kematian tanaman [2][3][4]. Peneliti lain juga melaporkan bahwa semakin lama biji cabai rawit diradiasi UVC, maka dapat mempengaruhi kerapatan stomata, kadar klorofil dan kadar kapsaisin dari buah yang dihasilkan [5].

ravitasi bumi juga merupakan salah satu faktor lingkungan yang sangat berpengaruh pada segala kehidupan di bumi. Nilai gravitasi di permukaan bumi, adalah sebesar $1 \mathrm{~g}$ yaitu sekitar $9,8 \mathrm{~ms}^{-2}$ Semua kehidupan di bumi merespon dan sudah beradaptasi terhadap gravitasi tersebut, baik terhadap tingkat seluler maupun molekuler [6]. Akar tanaman selalu mengarah menuju gravitasi, yaitu ke arah pusat bumi yang disebut geotropism positif, sedangkan tunasnya menunjukkan geotropism negatif yaitu tumbuh melawan gaya gravitasi.

Para ahli biologi juga telah mengembangkan eksperimen-eksperimennya untuk mempelajari kehidupan organisme di lingkungan gravitasi rendah yaitu lingkungan dengan nilai percepatan gravitasi kurang dari g. Lingkungan ini sering disebut sebagai keadaan mikrogravitasi (gravitasi berorde mikro $\left(10^{-6}\right)$ ). Sugano, M., dkk. 2002 telah melaporkan bahwa hasil fotosintesis dari bunga Sakura Jepang, yang mana biji atau benihnya telah diberikan perlakuan mikrogravitasi mengalami peningkatan dibandingkan dengan biji tanpa perlakuan mikrogravitasi [7].

Berdasarkan latar belakang tersebut di atas, maka sangat penting untuk meneliti tentang pengaruh dari paparan radiasi UVC dan mikrogravitasi pada biji cabai terhadap laju pertumbuhan dari tanaman cabai rawit. Pada penelitian ini, digunakan tanaman cabai rawit karena cabai rawit merupakan salah satu jenis sayuran penting yang dibudidayakan secara komersial dan memiliki potensi ekonomis cukup tinggi. Tanaman cabai rawit termasuk tanaman dengan umur pendek dan merupakan salah satu bahan pangan yang digunakan sehari-hari.

\section{Metode Eksperimen}

Pada penelitian ini biji cabai yang digunakan adalah jenis cabai rawit cap Bintang Asia. Lingkungan mikrogravitasi dibuat dengan menggunakan klinostat 2-D dengan kecepatan rotasi $2,7 \mathrm{rpm}\left(1,2 \times 10^{-4}\right.$ g)[8]. Sumber radiasi UVC yang digunakan adalah lampu UVC Sankyo Denki G20T10, 20 watt dengan jarak penyinaran $5 \mathrm{~cm}$. Biji cabai diradiasi selama 1 jam kemudian diberikan perlakuan mikrogravitasi dengan variasi waktu yaitu 12 jam (S5), 24 jam (S6), dan 48 jam (S7). Sebagai kontrol digunakan biji cabai tanpa perlakuan (S0), biji cabai dengan penyinaran UVC selama 1 jam (S1) dan biji cabai dengan mikrogravitasi selama 12 jam (S2), 24 jam (S3), dan 48 jam (S4). Pengukuran tinggi dan jumlah tanaman yang hidup dilakukan dari umur tanaman 0-40 hari (fase vegetatif). Dari data tinggi tanaman dapat diplot grafik sebagai fungsi waktu. Laju pertumbuhan tanaman dapat ditentukan dengan melakukan kurva fitting yaitu regresi linear, yang menghasilkan persamaan $y=a x+b$, dimana $a$ adalah laju pertumbuhan. Persentase tanaman hidup dapat dihitung dengan menggunakan Persamaan 1.

Tanaman hidup $(\%)=\frac{\text { Jumlah tanaman hidup }}{\text { Jumlah biji tanaman }} \times 100 \%$

\section{Hasil dan Pembahasan}

Dari data hasil pengukuran tinggi tanaman cabai rawit dari seluruh sampel pada hari ke-0 sampai 40, dapat dihitung tinggi tanaman cabai rata-rata dan standar 
deviasinya, selanjutnya dibuat grafik antara tinggi tanaman sebagai fungsi waktu seperti tampak pada Gambar 1.

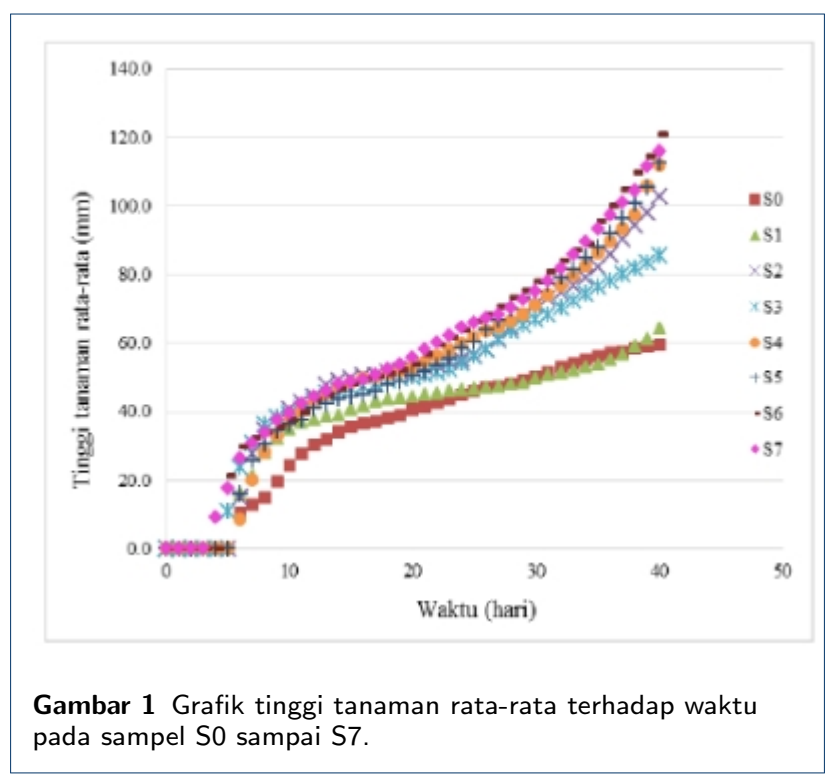

Gambar 1 memperlihatkan bahwa pertumbuhan tinggi tanaman cabai menunjukkan 2 trend yaitu sangat cepat dan lambat, yang masing-masing disebut sebagai fase vegetatif I dan fase vegetatif II. Pada fase vegetatif I laju pertumbuhan tanaman lebih cepat dibandingkan fase vegatatif II, dimana grafik terlihat lebih landai. Dengan melakukan regresi linear, maka diperoleh laju pertumbuhan tanaman pada masing-masing sampel dan masing-masing fase seperti tampak pada Tabel 1. Untuk menggambarkan perbedaan laju pertumbuhan tinggi tanaman sampel kontrol: S0 sampai S4 dengan kelompok sampel perlakuan gabungan S5 sampai S7, maka data pada Tabel 1 dapat dibuat grafik laju pertumbuhan tinggi tanaman rata-rata dari masing- masing sampel pada fase vegetatif I dan fase vegetatif II, seperti pada Gambar 2.

Gambar 2 memperlihatkan bahwa laju pertumbuhan tanaman rata-rata seluruh sampel pada fase vegetatif I lebih tinggi dibandingkan pada fase vegetatif II. Fase vegetatif I disebut juga fase perkecambahan dimana tanaman mengalami pertumbuhan tinggi batang sangat cepat. Pada fase ini, sampel yang diberikan perlakuan UVC-mikrogravitasi 12 jam (S5) dan UVC-mikrogravitasi 48 jam (S7) mengalami laju pertumbuhan lebih kecil dibandingan dengan sampel UVC selama 1 jam (S1), sedangkan jika dibandingkan dengan sampel S0 laju petumbuhannya lebih besar.

Pada fase vegetatif II, laju pertumbuhan tanaman pada sampel UVC-mikrogravitasi 12 jam (S5) dan UVC- mikrogravitasi 48 jam (S7) lebih besar

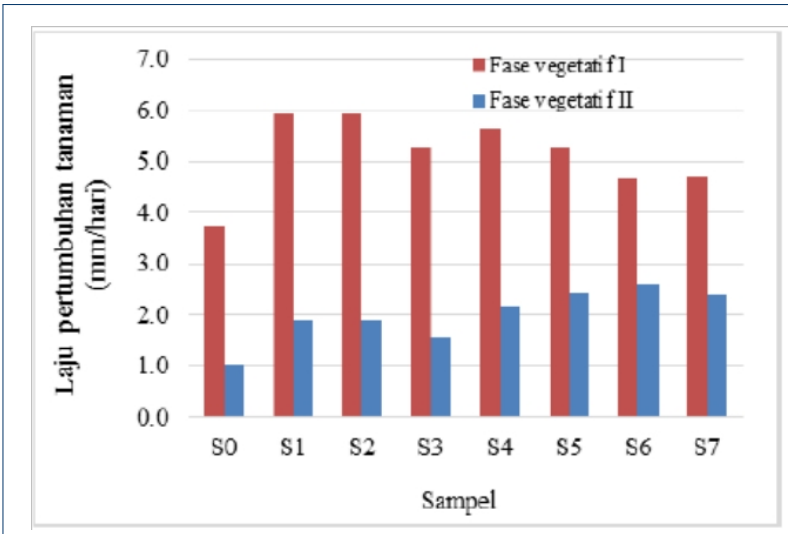

Gambar 2 Grafik laju pertumbuhan tinggi tanaman rata-rata masing-masing sampel pada fase vegetatif I dan II.

\begin{tabular}{|c|c|c|}
\hline \multirow{2}{*}{ Sampel } & \multicolumn{2}{|c|}{$\begin{array}{c}\text { Laju Pertumbuhan Tinggi } \\
\text { Tanaman Rata-rata (mm/hari) }\end{array}$} \\
\cline { 2 - 3 } & Fase vegetatif I & Fase vegetatif II \\
\hline S0 & $3,7 \pm 0,2$ & $1,0 \pm 0,0$ \\
S1 & $5,9 \pm 0,6$ & $1,9 \pm 0,1$ \\
S2 & $5,9 \pm 0,6$ & $1,9 \pm 0,1$ \\
S3 & $5,3 \pm 0,6$ & $1,5 \pm 0,1$ \\
S4 & $5,6 \pm 0,4$ & $2,2 \pm 0,1$ \\
S5 & $5,3 \pm 0,6$ & $2,4 \pm 0,1$ \\
S6 & $4,7 \pm 0,8$ & $2,6 \pm 0,1$ \\
S7 & $4,7 \pm 0,5$ & $2,4 \pm 0,1$ \\
\hline
\end{tabular}

Tabel 1 Laju pertumbuhan tinggi tanaman rata-rata masing-masing sampel S0 samapai S7

dibandingkan dengan sampel S1, demikian juga jika dibandingkan dengan sampel S0 (kontrol) maupun sampel mikrogravitasi 12 jam (S2) dan mikrogravitasi 48 jam (S4). Hal ini menunjukkan bahwa perlakuan mikrogravitasi pada biji cabai memberikan pengaruh negatif pada fase vegetatif I dan berpengaruh positif pada fase vegetatif II. Pada fase ini, laju pertumbuhan seluruh sampel cenderung melambat karena pada fase vegetatif II terdapat hormon kalin yang merangsang pertumbuhan organ tanaman seperti akar, batang, cabang, dan daun.

Hormon ini menyebabkan pertumbuhan cabang dan daun baru di sekitar batang utama sehingga pertumbuhan tanaman cenderung melambat. Berdasarkan hasil uji statistik yang dilakukan, menunjukkan hampir seluruh sampel memiliki perbedaan yang signifikan. Dari hasil penelitian selama fase vegetatif (0-40 hari), diperoleh persentase hidup tanaman cabai rawit kontrol maupun dengan perlakuan adalah $100 \%$.

\section{Kesimpulan}

Berdasarkan hasil-hasil tersebut di atas, maka dapat disimpulkan bahwa dengan perlakuan mikrogravitasi pada biji cabai rawit yang sudah diradiasi UVC 
selama 1 jam dapat memberikan pengaruh negatif atau positif terhadap laju pertumbuhan tanaman cabai. Besar pengaruh bergantung pada lama perlakuan yang diberikan dan fase pertumbuhan tanaman.

\section{Ucapan Terimakasih}

Terimakasih kepada Jurusan Fisika, FMIPA Universitas Udayana serta Laboratorium Bersama Fakultas Matematika dan Ilmu Pengetahuan Alam, Universitas Udayana atas segala fasilitasnya.

\section{Penulis}

1 Ni Nyoman Rupiasih.

Dari :

(1) Department of Physics, Faculty of Mathematics and Natural Sciences, Udayana University, Bali, Indonesia

(2) Group Research Material and Technology-Polymer and Biomaterial, Udayana University, Bali, Indonesia

2 Made Sumadiyasa

Dari :

(1) Department of Physics, Faculty of Mathematics and Natural Sciences, Udayana University, Bali, Indonesia

3 Ni Kadek Gita Hari Yanti

Dari :

(1) Department of Physics, Faculty of Mathematics and Natural Sciences, Udayana University, Bali, Indonesia

Pustaka

1. Katerova, Z., et al., Low doses of ultraviolet-B or ultraviolet- $C$ radiation affect $A C C, A B A$ and IAA levels in young pea plants. Biol. Plant., vol. 53, no. 2, 2009, pp. 365-368.

2. N. Nyoman Rupiasih and Pandit B. Vidyasagar, Effect of UV-C Radiation and Hypergravity on Germination, Growth and Content of Chlorophyll of Wheat Seedlings, AIP Conference Proceedings 1719, 030035, 2016, doi: 10.1063/1.4943730.

3. Adriano, S., Antonio Scopa, Donato Castronuovo, Giuseppe Tataranni, Stella Lovelli, Vincenzo Candido, UV-C Irradiation Effects On Young Tomato Plants: Preliminary Results, Universitas Basilicata, Italia, vol. 46, no. 3, 2014, pp. 945-949.

4. Ni Nyoman Rupiasih, R.A. Restia Pranagari, Hery Suyanto, Nyoman Wendri, Pengaruh Lama Penyinaran UVC Pada Biji Cabai Rawit (Capsicum Frustescent L.) Terhadap Laju pertumbuhan Dan Kualitas Panen Buah Cabai. Prosiding SFN XXVIII, 2015, pp. 42-52.

5. Ni Nyoman Rupiasih, Hery Suyanto and Fauziyah, Pengaruh Dosis Radiasi UV-C Pada Benih Tomat
Terhadap Laju Pertumbuhan Dan Kadar Klorofil-A Tanaman Tomat Sampai Pada Masa Vegetatif, Proceeding Seminar Nasional Fisika, 2011, pp. 1085-1093.

6. Sugano, M., Uno, Y., Nakamura, T., Growth and Photosynthesis of Japanese Flowering Cherry under Simulated Microgravity Conditions, Biological Sciences in Space, vol. 16, no. 4, 2002, pp. 242-244.

7. Hoson T., et al., Evaluation of the Three-Deminsional Clinostat as a Simulator of Weightlessness, Planta, vol. 203, 1997, pp. 187-197.

8. Antara, Oka Guna, 2015. Rancang Bangun Klinostat 2-D Dengan Perotasi Motor DC D06D401E, Buletin Fisika, vol. 17 , no. 2, August 2016, pp. 25-33. 